\title{
PRIVATIZAÇÃo do SETOR DE SANEAMENTO NO BRASIL: QUATRO EXPERIÊNCIAS E MUITAS LIÇÕES
}

Marina Figueira de Mello ${ }^{\S}$

\section{RESUMO}

Este trabalho analisa quatro estudos de caso de concessões, ao setor privado, na área de saneamento no Brasil. A análise se concentra na política tarifária, no impacto do modelo dos leilões sobre os preços futuros e no formato da regulação. As principais conclusões são que a política tarifária é ineficiente e iníqua. O modelo do leilão é muito relevante para a determinação dos preços futuros e deve privilegiar a menor tarifa como critério de escolha. A regulação, além de instável e confusa, está incompleta.

Palavras-chave: privatização, saneamento, tarifas.

\section{ABSTRACT}

This paper goes through four case studies of the water sector concessions to the private sector in Brazil. The analysis comprises mainly the pricing policies, the impact of the auction modeling on future tariffs and regulatory practices. The main conclusions are that the pricing policies are inefficient and unfair and should be completely remodeled. The auction design affects future tariffs and should focus the lowest price. The regulatory framework is incomplete and not clear.

Key words: privatization, water, tariffs.

JEL classification: L33, G38.

$\S$ A autora, do Departamento de Economia da PUC-Rio, agradece ao BNDES pelo apoio. Agradece também a um parecerista anônimo e aos alunos Luis Fernando de Azevedo Lopes e Maria Gabriela Podcameni pelo competente trabalho de assistência à pesquisa.

Recebido em novembro de 2003. Aceito em junho de 2005. 


\section{INTRODUÇÃO}

No segundo semestre de 2003, o governo do Presidente Lula encaminhou ao Congresso Nacional um projeto de lei instituindo a PPP - Parceria Público-Privada no âmbito da administração pública. Tal parceria tem por objetivo estabelecer novo marco de relacionamento entre os setores público e privado, em substituição ao programa de privatização do governo anterior. Torna-se, portanto, muito oportuna uma avaliação do que vinha sendo feito até então. Na medida em que há indícios de que o setor público voltará a investir diretamente na área de saneamento, a avaliação das poucas experiências de privatização que foram implementadas até agora certamente será fonte de referência futura.

O objetivo deste trabalho é descrever, por meio de quatro estudos de caso, as iniciativas de privatização implementadas no setor de saneamento no governo Fernando Henrique Cardoso. Tratase, sabidamente, de um setor no qual a insuficiência de recursos para investimento vem causando danos inestimáveis. ${ }^{1}$ Este artigo pretende criticar a forma como as concessões foram feitas no passado e sugerir medidas para seu aprimoramento.

As primeiras iniciativas de privatização no saneamento foram implementadas com uma enorme indefinição no ambiente regulatório, que ainda permanece. A Constituição de 1988 implantou o domínio público dos corpos de água. O domínio da União abrange rios e lagos que banhem mais de uma unidade da federação, ou que sirvam de fronteira interestadual ou internacional. Os estados detêm o domínio das águas superficiais ou subterrâneas, fluentes, emergentes e em depósito. Os municípios não têm direitos a águas próprias.

Uma vez que o saneamento é uma questão de interesse local, os governos municipais têm a obrigação de prestar o serviço e o direito de conceder, mas não há clareza das responsabilidades envolvidas nas regiões metropolitanas que abrangem mais de um município. Nestes casos, há quem defenda que a responsabilidade pelo serviço deva ser transferida para o governo estadual. ${ }^{2}$ Também, ainda não há regras definidas para a obtenção, pelos governos municipais, da água necessária para a distribuição. Por isso, a concessão dos serviços depende de acordos entre as prefeituras e as demais esferas de governo. ${ }^{3}$

Atualmente, a legislação básica em vigor é composta pelas seguintes leis principais: Lei 8987 de 13/02/95, chamada Lei das Concessões, que estabelece normas para a participação privada nos projetos de infra-estrutura e na prestação de serviços de utilidade pública; Lei 9433 de 8/01/97, que criou o sistema nacional de gerenciamento de recursos hídricos por bacias hidrográficas (e não por fronteiras políticas ou administrativas) e definiu os direitos de outorga pela utilização da água em bruto; Decreto 3692 de 19/12/2000, que criou a ANA - Agência Nacional de Águas; e Portaria do Ministério da Saúde n⿳0 1469/2000, que estabelece padrões de qualidade para a água potável.

No Estado do Rio de Janeiro a ASEP - Agência Reguladora de Serviços Públicos faz a regulação da prestação de serviços de saneamento. A Lei estadual 2831/97 trata da concessão de serviços públicos e a Lei 2869/97 do regime de prestação de serviços públicos de saneamento básico. Finalmente, o Decreto 22.872 de 28/12/96 regulamenta os serviços de saneamento a cargo das concessionárias.

1 O Programa Plurianual PPA para o setor de saneamento pretende ampliar a cobertura dos serviços urbanos de coleta e tratamento de esgotos de 50,9\% para 57,9\% no período 2004 a 2007, com investimentos totais estimados em cerca de R $\$ 5$ bilhões anuais.

2 O Brasil tem cerca de 5.500 municípios. Caso este princípio venha a ser acatado, em cerca de 5.200 os serviços serão locais. Nos 300 restantes, a titularidade seria compartilhada. Além disso, soma aproximadamente 1.300 o número de municípios autônomos, isto é, que têm empresas municipais encarregadas do serviço.

3 Por exemplo, depois de longa batalha judicial, a prefeitura de Niterói teve seu direito à titularidade do serviço garantida em novembro de 1999. A nova concessionária privada, com contrato assinado, não pode assumir os serviços por quase três anos, entre outras razões porque não havia acordo sobre o preço pelo qual a água tratada deveria ser vendida à prefeitura pela CEDAE, empresa estatal estadual. Num convênio assinado em novembro de 1988 ficou acertado que a CEDAE venderia água a Niterói a R $\$$ 0,30 por $\mathrm{m}^{3}$. Quase um ano depois, a CEDAE considerou o preço muito baixo, e passou a exigir R\$ 0,58. (O Globo 14/10/99). 
Este trabalho tem cinco seções. Após esta introdução, a segunda seção faz uma descrição da modelagem de venda de quatro concessões plenas feitas ao setor privado entre 1995 e 1998: Limeira - SP; Petrópolis - RJ; e duas concessões na chamada Região dos Lagos - RJ. A terceira seção faz uma análise crítica das políticas tarifárias adotadas, relacionando-as à modelagem das vendas. A seção IV descreve características dos processos regulatórios que seriam implementados para estas empresas, seguida das conclusões.

\section{QUATRO CONCESSÕES AO SETOR PRIVADO}

\section{II.1 Características básicas}

A tabela abaixo contém a lista das características básicas das concessões avaliadas neste trabalho com base na análise de seus Editais de Privatização e Contratos de Concessão. ${ }^{4}$ Este conjunto foi selecionado por se tratar de experiências pioneiras de concessão plena (água e esgoto). Antes da privatização, o potencial turístico dessas áreas (exclusive Limeira) vinha sendo prejudicado pela irregularidade no abastecimento de água potável e pela falta de esgotamento sanitário. Tanto em Petrópolis como na Região dos Lagos, os esgotos vinham sendo despejados sem tratamento nos rios e praias dos respectivos municípios através da rede pluvial. As perdas de água e o grau de inadimplência dos consumidores eram também muito elevados.

\begin{tabular}{|c|c|c|c|c|c|}
\hline Concessionária & Área de Concessão & $\begin{array}{l}\text { Data da } \\
\text { Privatização }\end{array}$ & $\begin{array}{l}\text { Prazo da } \\
\text { Concessão }\end{array}$ & $\begin{array}{l}\text { Investimentos } \\
\text { Previstos em } \\
\mathrm{R} \$ \text { milhões }\end{array}$ & $\begin{array}{l}\text { Critério de Seleção } \\
\text { além da Proposta } \\
\text { Técnica }\end{array}$ \\
\hline $\begin{array}{l}\text { Águas de } \\
\text { Limeira }\end{array}$ & Limeira - SP & 02/06/95 & 30 anos & 100 & Menor tarifa \\
\hline $\begin{array}{l}\text { Águas do } \\
\text { Imperador }\end{array}$ & Petrópolis - RJ & $22 / 10 / 97$ & 30 anos & 80 & $\begin{array}{l}\text { Menor tarifa e maior } \\
\text { valor de outorga }\end{array}$ \\
\hline Prolagos & $\begin{array}{l}\text { Cabo Frio, Búzios, São Pedro da } \\
\text { Aldeia, Iguaba e Arraial do Cabo - RJ }\end{array}$ & $1 / 12 / 97$ & 25 anos & 70 & $\begin{array}{l}\text { Maior valor } \\
\text { de outorga }\end{array}$ \\
\hline $\begin{array}{l}\text { Águas do } \\
\text { Juturnaíba }\end{array}$ & $\begin{array}{l}\text { Araruama, Iguabinha, São Vicente de } \\
\text { Paula, Saquarema, Bacaxá, Praia } \\
\text { Seca e Silva Jardim - RJ }\end{array}$ & $25 / 04 / 98$ & 25 anos & 197 & $\begin{array}{l}\text { Maior valor de } \\
\text { outorga }\end{array}$ \\
\hline
\end{tabular}

\section{II.2 Editais: requisitos para participação nos leilóes}

Os melhores resultados para a privatização são obtidos quando há disputa efetiva pela concessão. Por isso, é desejável ter-se o maior número possível de candidatos habilitados a participar do leilão. A restrição à participação de empresas estrangeiras pode ter o efeito de reduzir muito o número de interessados, principalmente quando há a necessidade de investimentos altos. A legislação brasileira determina que nas licitações para a concessão de serviços públicos as empresas estrangei-

4 O Edital de Limeira não estava disponível e, portanto, não foi analisado. 
ras podem participar isoladamente ou dentro de um consórcio com empresas brasileiras. Entretanto, na eventualidade de um consórcio, a empresa brasileira deve ser a líder. $\mathrm{O}$ edital da área de Petrópolis vetou a participação de empresas estrangeiras exceto em consórcio com empresa nacional. Nos demais editais a participação isolada de empresas estrangeiras foi permitida.

Há outras formas de restrição do número de participantes que podem ser definidas no edital como pré-requisitos para participação. Idealmente, tais exigências devem ser formuladas com o objetivo de promover a melhor solução no que diz respeito à confiabilidade do novo concessionário, mas podem também ser utilizadas para discriminar a favor ou contra determinados concorrentes. No Brasil, praticamente não há empresários com comprovada experiência no setor de saneamento porque todo o setor vem sendo administrado pelo Estado há muitos anos. Assim, determinadas exigências de experiência prévia praticamente eliminam interessados sem parcerias com grupos estrangeiros.

Com o objetivo de garantir que os novos concessionários tenham uma situação econômica adequada, é costume incluir pré-requisitos como capital mínimo, coeficientes de endividamento e robustez financeira, garantias de propostas e exigências com relação à composição do capital. Por exemplo, no caso das Águas do Juturnaíba exigiu-se que a firma licitante tivesse um capital mínimo de $\mathrm{R} \$ 35$ milhões e, para a Prolagos, de $\mathrm{R} \$ 60$ milhões.

No que diz respeito à capacitação técnica, são normalmente formuladas exigências para o operador técnico responsável como experiência em construção, operação e manutenção de sistemas de adução de água tratada, de estações de tratamento de água, de sistemas de coleta e tratamento de esgoto e de sistemas de distribuição (medidas por número de economias ou volume de água em $\mathrm{m}^{3}$ ). Pode-se exigir ainda um compromisso mais firme do operador. Na concessão da Águas do Juturnaíba exigiu-se que o operador técnico tivesse $5 \%$ das ações ordinárias nominativas do capital social da empresa concessionária a ser constituída, e na Prolagos, 15\%, sendo no mínimo 7,5\% de ações ordinárias.

No caso das empresas componentes da amostra, os empresários nacionais vencedores das licitações foram principalmente consórcios de empreiteiras, e os estrangeiros, grandes empresas internacionais do setor. Em Limeira, o consórcio ganhador era formado pelas empresas CBPO Companhia Brasileira de Projetos e Obras, do grupo Odebrecht, e a francesa Lyonnaise des Eaux. $\mathrm{Na}$ licitação de Petrópolis, foi vencedor um consórcio das seguintes empreiteiras: Queiroz Galvão, Covan, Developer SA e Trana Construções. A concessionária Águas do Juturnaíba foi também formada por cinco empresas de construção civil: Cowan, Developer SA, Erco, EIT - Empresa Industrial Técnica e Queiroz Galvão. Finalmente, o consórcio Prolagos era formado pela Bozzano Simonsen, TEM Engenharia, Monteiro Aranha e EPAL - Empresa Portuguesa de Águas Livres.

\section{II.3 Modelo do leilão}

O modelo do leilão pode ou não conter os incentivos adequados para que a privatização traga os benefícios almejados. Em três dos casos analisados o leilão foi feito pela menor tarifa, mas o valor oferecido ao poder público pelos direitos de outorga fez parte dos critérios de seleção das propostas vencedoras. Esta tributação dissimulada onera o concessionário, dificultando a transferência dos ganhos da privatização à população mediante a cobrança de tarifas mais baixas.

No caso de Limeira, o leilão foi feito simplesmente pela menor tarifa TRA - Tarifa Referencial de Água, ou seja, sem o pagamento pelos direitos de outorga, porque a cobrança de tais encargos só veio a ser disciplinada em lei depois da realização do leilão. Nos outros três casos analisados, a outorga foi cobrada. O vencedor da licitação de Limeira seria aquele que oferecesse a menor tarifa 
referencial, à qual seria aplicada uma série de multiplicadores para gerar a tabela de preços de uma estrutura tarifária predefinida. A tarifa referencial ganhadora foi $\mathrm{R} \$ 0,55$ por $\mathrm{m}^{3}$. O contrato de concessão foi assinado pelo prefeito de Limeira como representante do poder concedente.

O vencedor da licitação de Petrópolis foi escolhido mediante uma ponderação da melhor proposta técnica (com $80 \%$ de peso) e maior valor para o fator de outorga (com $20 \%$ de peso). O Fator de Outorga (FO) era uma porcentagem das receitas da concessão a ser paga mensalmente ao governo. Embora o Fator de Outorga não fosse a variável mais importante para a definição do vencedor porque, como vimos, representava apenas $20 \%$ do peso final, sua expressão foi feita pela engenhosa fórmula:

$$
\begin{gathered}
\mathrm{FO}=0,025+0,20\left(0,43 \mathrm{R} \$ / \mathrm{m}^{3}-\mathrm{TRA}\right) \\
0,43 \mathrm{R} \$ / \mathrm{m}^{3}
\end{gathered}
$$

onde TRA é o valor da Tarifa Referencial de Água, expressa em $\mathrm{R} \$$ por $\mathrm{m}^{3}$, ofertada pela empresa licitante.

De acordo com esta fórmula, a porcentagem da receita destinada ao pagamento da outorga podia ser calculada a partir de um lance para a TRA - Tarifa Referencial de Água. O valor da outorga seria mínimo, isto é, 2,5\%, quando a TRA fosse máxima, ou seja, $\mathrm{R} \$ 0,43$.

$\mathrm{Na}$ medida em que o que interessa ao concessionário é a maximização de sua tarifa líquida dos pagamentos da outorga (TL), e não a tarifa bruta que aparece no modelo de licitação (TRA), vale a pena expressar a relação entre a tarifa líquida (TL) e Fator de Outorga (FO) para ficar mais clara a tensão entre o objetivo de vencer a licitação, mediante o oferecimento de um FO mais elevado, e a geração de receitas líquidas elevadas, o que exigiria um FO baixo:

$$
\mathrm{TRA}=\mathrm{TL}+\mathrm{FO}^{*} \mathrm{TRA} \Rightarrow \mathrm{TRA}=\mathrm{TL} /(1-\mathrm{FO})
$$

A fórmula (1) pode ser reescrita como:

$$
F O=0,025+0,2 .\left(1-\frac{T R A}{0,43}\right)
$$

Donde se pode expressar TRA em função de FO:

$$
T R A=0,43\left[\frac{0,2-F O+0,025}{0,2}\right]
$$

Substituindo (2) em (3), chega-se à:

$$
T L=\frac{0,43 \cdot(1-F O)(0,225-F O)}{0,2}
$$

onde se pode ver claramente que a redução do fator de outorga aumentaria a receita líquida. Por outro lado, um FO elevado era necessário para vencer a licitação. 
Neste modelo de leilão os valores propostos para a TRA menores do que o teto de $\mathrm{R} \$ 0,43$ significavam receitas menores para o novo concessionário, não apenas porque a tarifa seria menor, mas também porque o valor da outorga seria maior. O restante da estrutura tarifária seria obtido, como em Limeira, mediante a aplicação de multiplicadores fixos à TRA. ${ }^{5}$ A TRA vencedora do leilão foi $\mathrm{R} \$ 0,30$, o que significou uma outorga de $8,54 \%$. Sem cobrança pela outorga este valor seria necessariamente menor, beneficiando a população.

O contrato de concessão de Petrópolis foi realizado como uma subconcessão na qual a concessionária estatal CAEMPE - Companhia de Água e Esgoto do Município de Petrópolis transferiu seus direitos de concessão à vencedora do leilão de privatização como forma de evitar uma discussão da própria decisão de privatizar pela Câmara de Vereadores.

O formato dos leilões vencidos por Prolagos e Águas do Juturnaíba teve muitas semelhanças, determinando-se o vencedor por ponderação das propostas técnicas e maior valor da outorga, dada uma estrutura tarifária preestabelecida, construída a partir de uma TRA básica de $\mathrm{R} \$ 0,45$. Nas experiências da Região dos Lagos, tanto o estado como os municípios envolvidos foram considerados poderes concedentes, e tanto o governador como os prefeitos assinaram o contrato de concessão.

Desta vez, o pagamento da outorga deveria ser feito num prazo muito curto, por meio de prestações de montante fixo, e não como uma proporção da receita mensal de vendas. ${ }^{6}$ A primeira prestação seria devida imediatamente, na data da Ordem do Início dos Serviços, e as restantes seriam pagas em 22 parcelas anuais sucessivas, no caso da Águas do Juturnaíba, e 24, no caso da Prolagos, cujo valor seria proposto pelas licitantes. Os Editais estipularam um valor mínimo para outorga de $5 \%$ da receita líquida prevista para a concessão. A receita proveniente dos direitos de outorga, tanto para Juturnaíba como para a Prolagos, é dividida entre as entidades que integram o poder concedente da seguinte forma: $50 \%$ para o estado e $50 \%$ para os municípios da área de concessão proporcionalmente às populações censitárias.

\section{II.4 Contratos de concessão: reversão de ativos}

$\mathrm{Na}$ medida em que as concessões não implicam transferência de propriedade, os ativos devem reverter ao poder público ao final da concessão. Este modo de privatização traz embutido um incentivo a não fazer investimentos perto do final do prazo da concessão. Os contratos analisados, de uma maneira geral, determinam que esta transferência se dê sem nenhuma indenização, exceto a parte referente a investimentos não amortizados. Os contratos analisados procuram atenuar o risco de receber os ativos em mau estado de conservação, prevendo a possibilidade de renovação (Prolagos), pedindo depósitos em garantia (Juturnaíba) ou fazendo exigências contratuais nesse sentido.

\section{POLÍTICA TARIFÁRIA}

As iniciativas de privatização quase sempre foram objeto de muita contestação política. Por esta razão, seus promotores até agora procuraram minimizar a exposição ao debate. Como os preços são talvez a parte mais visível do relacionamento das concessionárias com o público, tem sido comum que a privatização seja feita sem alterações substantivas da política tarifária, o que tem produzido maus resultados porque a política tarifária das empresas estatais é geralmente muito inefici-

5 Num arranjo casuísta, além do pagamento da outorga, o novo concessionário de Petrópolis foi obrigado a pagar uma taxa fixa de $\mathrm{R} \$ 400$ mil a título de aluguel dos imóveis e veículos da prefeitura.

6 No caso da Águas de Juturnaíba, no julgamento das propostas técnicas houve incentivos, expressos em pontos, para contratação de ex-empregados da CEDAE. 
ente e iníqua e porque sua manutenção num contrato de concessão de longo prazo impossibilita as mudanças necessárias num futuro próximo.

A política herdada do setor público é muito ineficiente. Os preços variam por classes de consumidores e faixas de consumo numa intrincada malha de subsídios cruzados cuja lógica pode ser facilmente contestada. Assim, o preço por $\mathrm{m}^{3}$ de água fornecida é diferente, dependendo do uso que vai ser dado à água, sem que haja qualquer razão para acreditar que o custo de fornecimento de $\mathrm{um} \mathrm{m}^{3}$ de água para o comércio seja muito diferente do abastecimento deste mesmo $\mathrm{m}^{3}$ para uma residência ou repartição pública. Essa discriminação de preços por classes de consumidores é feita por considerações de eqüidade cuja conveniência política é muito discutível.

A atual política de preços do setor de saneamento é totalmente desvinculada dos custos de atendimento. Por exemplo, o serviço de esgotamento sanitário, com ou sem tratamento, é cobrado numa determinada proporção do preço da água fornecida, (freqüentemente 100\%) sem considerar que o custo de coleta e tratamento de um $\mathrm{m}^{3}$ de esgoto é muito diferente do custo de produção de um $\mathrm{m}^{3}$ de água potável e depende muito do tipo de esgoto que está sendo coletado. A prática de cobrar pelo esgotamento em função do fornecimento de água vem sendo justificada pelo fato de que o esgotamento não é medido.

Há ainda tarifação em blocos, aumentando-se o preço para faixas de consumo mais altas, cujo objetivo é induzir um comportamento poupador. Entretanto, tal incentivo à redução do desperdício não é tão forte no setor de saneamento quanto em outros setores. No saneamento, é impossível tratar os consumidores individualmente quando eles compartilham um prédio ou um centro comercial, por exemplo. Em situações como estas, todas as unidades têm obrigatoriamente uma mesma ligação de água, sendo o prédio considerado uma unidade autônoma para efeito de cadastramento e cobrança. Assim, um condomínio com 50 apartamentos é entendido como uma ligação de água com 50 economias. A cada economia corresponde um consumidor individual que, sem controle sobre o padrão de consumo de seus vizinhos, percebe que a redução do consumo de sua própria família terá muito pouca influência na determinação da conta total a pagar.

No que diz respeito à eqüidade, a tarifa em blocos também não é efetiva. Em primeiro lugar, a tarifa mínima é, na verdade, uma conta mínima para todas as ligações. Geralmente, aplica-se à faixa entre 0 e $10 \mathrm{~m}^{3}$ por mês. Como o padrão internacional de consumo de água é de 25 a 30 litros per capita por dia, numa casa com cinco pessoas, isto significa $4-5 \mathrm{~m}^{3}$ por mês ${ }^{7}$ e, portanto, cerca de metade do necessário para pagar apenas a conta mínima. Mesmo que no caso brasileiro este consumo possa ser mais elevado, a amplitude exagerada desta faixa inicial permite acomodar uma parcela grande das residências (eleitores) na conta mínima. Verifica-se que há muita pressão política para que esta faixa não seja reduzida. ${ }^{8}$

O preço fixo para o consumo até $10 \mathrm{~m}^{3}$ por mês tem o efeito de produzir um preço por $\mathrm{m}^{3}$ decrescente até o limite superior da faixa mínima. Assim, o consumidor de $8 \mathrm{~m}^{3}$ por mês paga menos por $\mathrm{m}^{3}$ do que o consumidor de $3 \mathrm{~m}^{3}$ por mês, e para aproveitar todo o subsídio, o consumidor tem que levar o seu consumo até o final da faixa mínima.

Talvez a crítica mais contundente que se possa fazer ao tipo de tarifação em bloco adotado pelas empresas brasileiras de saneamento é que não há muita evidência de que o elevado consumo de água signifique um alto padrão de vida, como é o caso da eletricidade, por exemplo. Se o elevado consumo de água for provocado por um também elevado número de habitantes por residência, a

7 Ver Gleick (1996); United Nations (1993) e WHO (1997).

8 Ver Boland e Wihttington (2000). 
tarifa em blocos vai significar iniqüidade. ${ }^{9}$ Ainda assim, atualmente o maior problema para os grupos de renda mais baixa é a não existência ou precariedade do serviço prestado.

O fato de a adoção de sistemas de tarifação em blocos pode não ter a progressividade desejada pode ser ilustrado no diagrama abaixo. Nele, o eixo horizontal contém a renda média domiciliar em cada um dos subdistritos do município do Rio de Janeiro. O eixo vertical contém o valor arrecadado no subdistrito por $\mathrm{m}^{3}$ de água distribuída pela CEDAE. Pode-se ver que praticamente não há progressividade, já que a arrecadação por $\mathrm{m}^{3}$ nos bairros de renda mais baixa é praticamente a mesma dos bairros de renda mais elevada. Embora este ponto mereça uma análise mais aprofundada, esta baixa progressividade provavelmente se deve ao fato de que o número de habitantes dos subdistritos mais pobres em cada domicílio é maior.

Valor médio arrecadado em serviços de água e esgoto por $\mathrm{m}^{3}$ de água fornecida pela CEDAE em cada subdistrito do Município do Rio de Janeiro

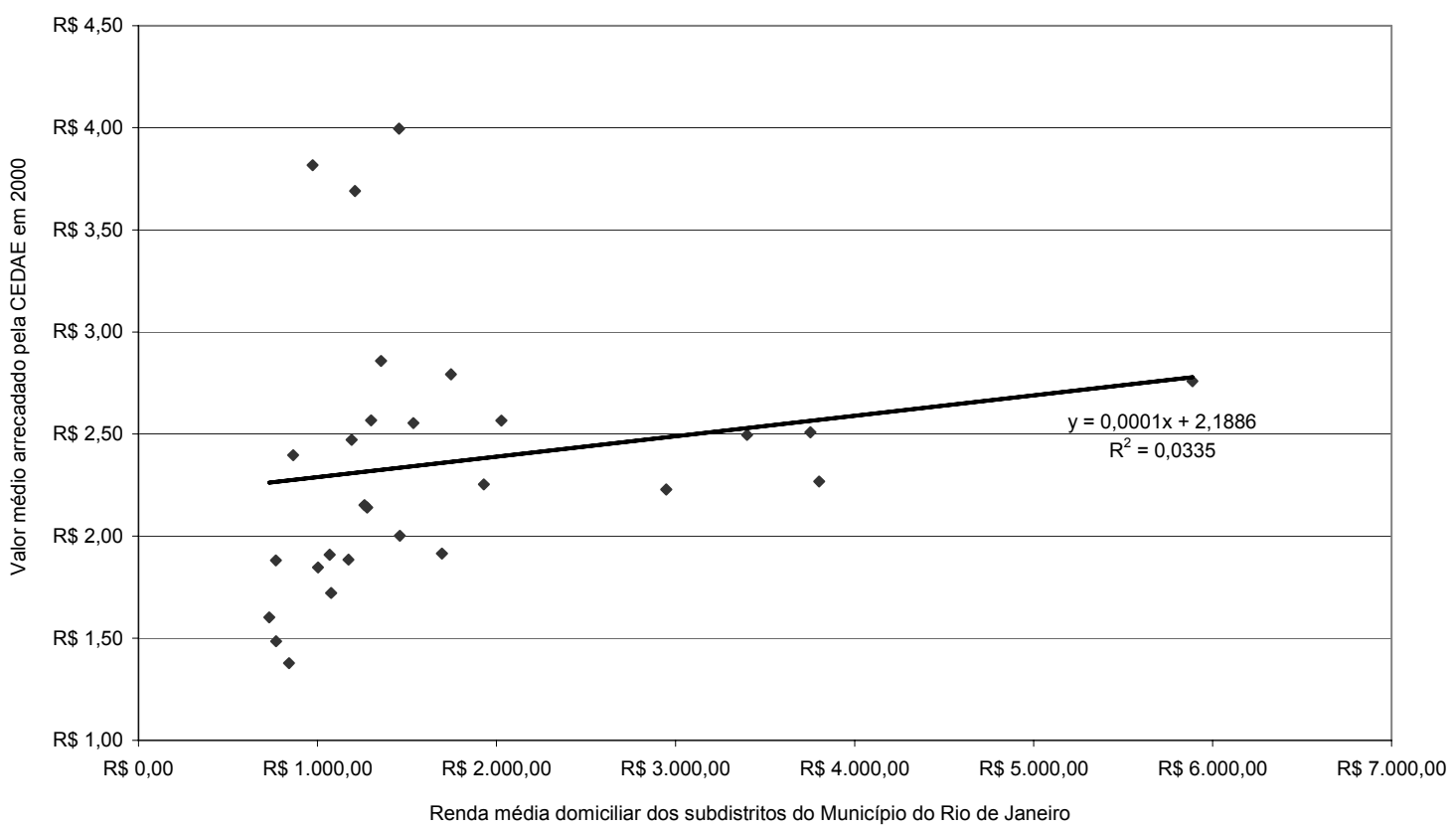

Fonte: Dados de Arrecadação: CEDAE (2000); Renda Média Domiciliar: IBGE, Censo Demográfico (2000).

Finalmente, deve-se considerar com muito cuidado a questão das concessões plenas. A prestação dos dois serviços (água e esgoto) por uma mesma empresa pode não ser desejável, já que não há evidências de economias de abrangência que justifiquem a privatização em conjunto. O Ofwat - Office of Water, regulador inglês do saneamento, constatou a existência de expressivas deseconomias de escopo na indústria. A partir de uma comparação dos custos de empresas especializadas em água com os custos de empresas de água e esgoto, inclusive algumas que haviam se fundido recentemente, o trabalho concluiu que não há razões de economias de custos para a aprovação de eventuais solicitações de fusões com integração horizontal dos serviços de água e esgoto. ${ }^{10}$ Em outras palavras, não há evidências de que a prestação conjunta de serviços de água e esgoto tenha custos mais baixos do que quando os dois serviços são prestados separadamente.

9 Segundo os dados do censo, no Rio de Janeiro o número de habitantes por domicílio é decrescente com o nível de renda familiar.

10 Stone \& Webster Consultants (2004), OFWAT - Office of Water. 
Este resultado não seria alterado ainda que pequenas economias de escopo tenham sido constatadas neste mesmo estudo na aquisição de insumos compartilhados, como energia elétrica, por exemplo, e no faturamento conjunto dos dois serviços. Isto porque, como o esgoto não é medido, sua cobrança normalmente é feita com base nos volumes de água fornecidos a cada consumidor individual. Os serviços de esgotamento não podem ser interrompidos em caso de inadimplência. Neste caso, interrompe-se o fornecimento de água.

O relatório mostrou ainda que há clara evidência de economias de escopo na integração vertical da produção e distribuição de água que resulta em custos totais mais baixos. Assim, a privatização deveria privilegiar a concessão separada dos serviços de água e esgoto.

\section{III.1 Águas de Limeira}

A estrutura tarifária de Limeira foi predefinida de forma escalonada, ${ }^{11}$ atribuindo-se igual valor às tarifas de água e esgoto. A Tabela I contém as tarifas de água para ligações com hidrômetro constantes de seu contrato de concessão. A concessão de Limeira não prevê tabela de cobrança para consumidores não-hidrometrados, e como uma forma de incentivar a universalização da hidrometração obriga a concessionária a cobrar apenas a conta mínima (um valor fixo até $15 \mathrm{~m}^{3}$ por mês) em caso de não haver medição. Com o objetivo de analisar o impacto da privatização sobre os preços praticados, o Gráfico I mostra a evolução das tarifas cobradas no município de Limeira de 1994 a 2001. Pode-se observar que a privatização não criou nem eliminou faixas de consumo.

Gráfico I - Águas de Limeira - Tarifa residencial de água para os consumos abaixo especificados (valores em R\$ de junho de 2001 corrigidos pelo IGP-DI)

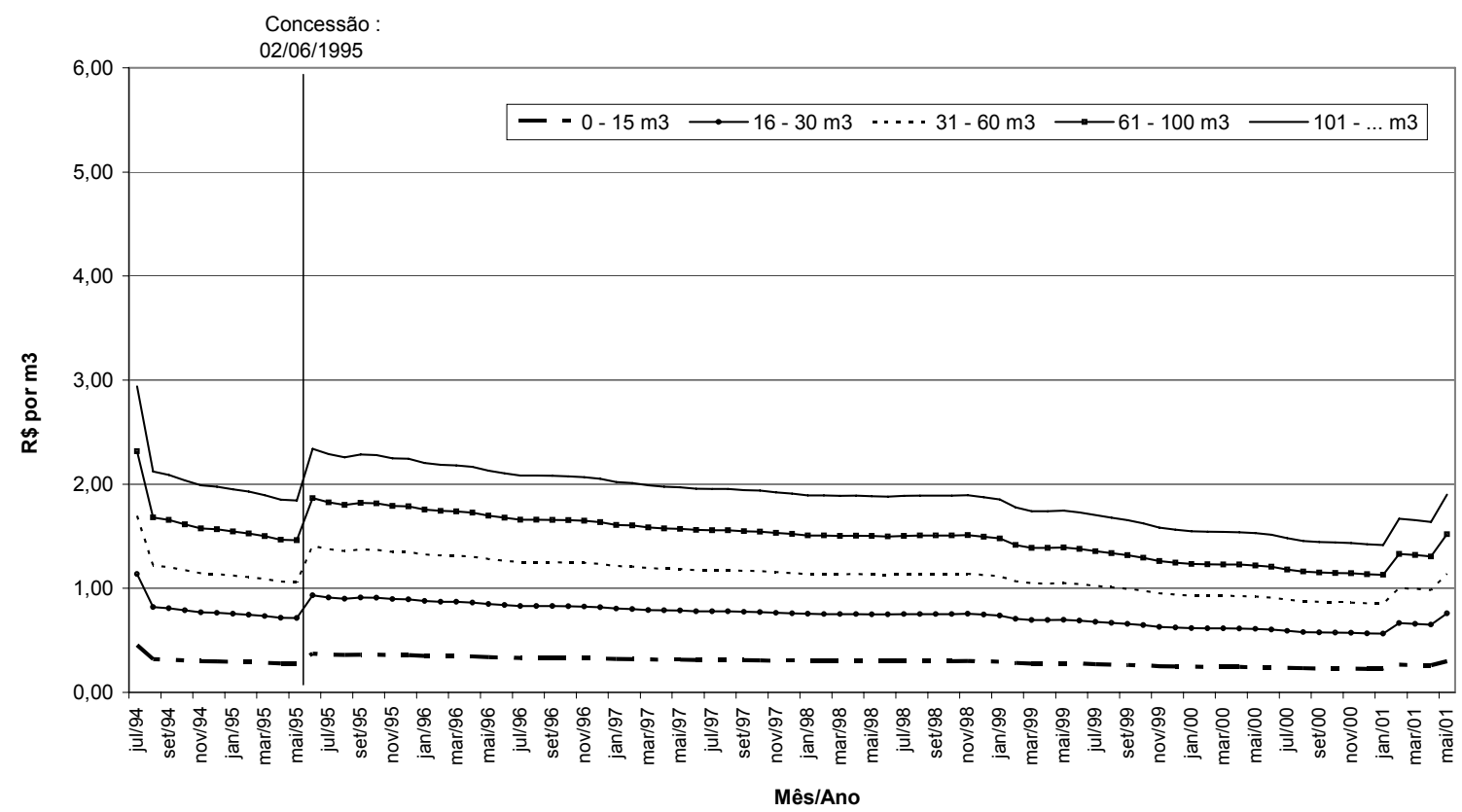

11 Chamamos a estrutura tarifária escalonada quando a cobrança é feita em blocos, com preços mais elevados para as faixas de consumo mais altas. No cálculo do valor da conta, cobra-se menos pelos primeiros $\mathrm{m}^{3}$ consumidos do que pelos últimos. A estrutura tarifária é chamada direta quando a um determinado volume consumido corresponde um único preço. No cálculo do valor da conta multiplica-se o montante consumido pelo preço único. 
Tabela I - Tarifa de água micromedida conforme o contrato de concessão

\begin{tabular}{ccc}
\hline \multicolumn{2}{c}{ Residencial } & $\mathrm{R} \$$ por $\mathrm{m}^{3}$ \\
\hline 0 & 15 & 0,22 \\
16 & 30 & 0,55 \\
31 & 60 & 0,83 \\
61 & 100 & 1,10 \\
101 & $\ldots$ & 1,38 \\
\hline & & \\
\hline Industrial & & $\mathrm{R} \$$ por $\mathrm{m}^{3}$ \\
\hline 0 & 15 & 0,55 \\
16 & 30 & 0,88 \\
31 & 60 & 1,43 \\
61 & 100 & 1,98 \\
101 & $\ldots$ & 2,53 \\
\hline
\end{tabular}

\begin{tabular}{ccc}
\hline Comercial & $\mathrm{R} \$$ por $\mathrm{m}^{3}$ \\
\hline 0 & 15 & 0,50 \\
16 & 30 & 0,83 \\
31 & 60 & 1,38 \\
61 & 100 & 1,93 \\
101 & $\ldots$ & 2,48 \\
\hline & & \\
\hline Pública & & $\mathrm{R} \$$ por $\mathrm{m}^{3}$ \\
\hline 0 & 15 & 0,28 \\
16 & 30 & 0,61 \\
31 & 60 & 0,88 \\
61 & 100 & 1,16 \\
101 & $\ldots$ & 1,43 \\
\hline
\end{tabular}

Em Limeira, além da determinação da conta mínima não há outras referências ao subsídio das pessoas de baixa renda. Reservou-se a isenção e tarifas reduzidas aos imóveis a serviço do município bem como o consumo destinado ao uso público, tais como hidrantes, chafarizes, irrigação de logradouros públicos, limpeza urbana e similares, em que a fonte deste subsídio estivesse definida. Tarifas mínimas são cobradas de instituições de caridade e hospitais. Como será analisado mais adiante neste trabalho, devido a uma inadequação na cláusula de reajuste do contrato de concessão, a nova concessionária trabalhou com a mesma tarifa nominal sem qualquer reajuste por quase seis anos, e só a partir de fevereiro de 2001 recebeu uma autorização de aumento de 63,4\% em três parcelas de cerca de $18 \%$ cada uma.

\section{III.2 Águas do Imperador}

A estrutura tarifária de Petrópolis também foi predefinida de forma escalonada, atribuindo-se às tarifas de esgoto $80 \%$ do valor das tarifas de água. A Tabela II contém as tarifas de água para ligações hidrometradas constantes do contrato de concessão. Com o objetivo de incentivar a concessionária a fazer uma rápida instalação de hidrômetros, esta foi obrigada a cobrar apenas a conta mínima, fixada em $10 \mathrm{~m}^{3}$ por mês de todas as ligações sem medição após o final do terceiro ano da concessão. Como a água é muito abundante e de boa qualidade em várias localidades da área de concessão, o consumidor com abastecimento próprio de água pode manter sua fonte própria, mas teve que aceitar sua hidrometração para pagar apenas pelo serviço de esgotamento. 
A privatização eliminou uma tarifa especial popular de $\mathrm{R} \$ 0,19 \mathrm{~m}^{3}$ por mês que vigorava nas localidades visivelmente habitadas por consumidores de baixa renda. O Gráfico II mostra a evolução das tarifas cobradas no município de Petrópolis de 1994 a 2001 para que se possa observar o efeito da privatização sobre a estrutura tarifária.

Gráfico II - Águas do Imperador - Tarifa residencial de água para os consumos abaixo especificados (valores em $\mathbf{R} \$$ de junho de 2001 corrigidos pelo IGP-DI)

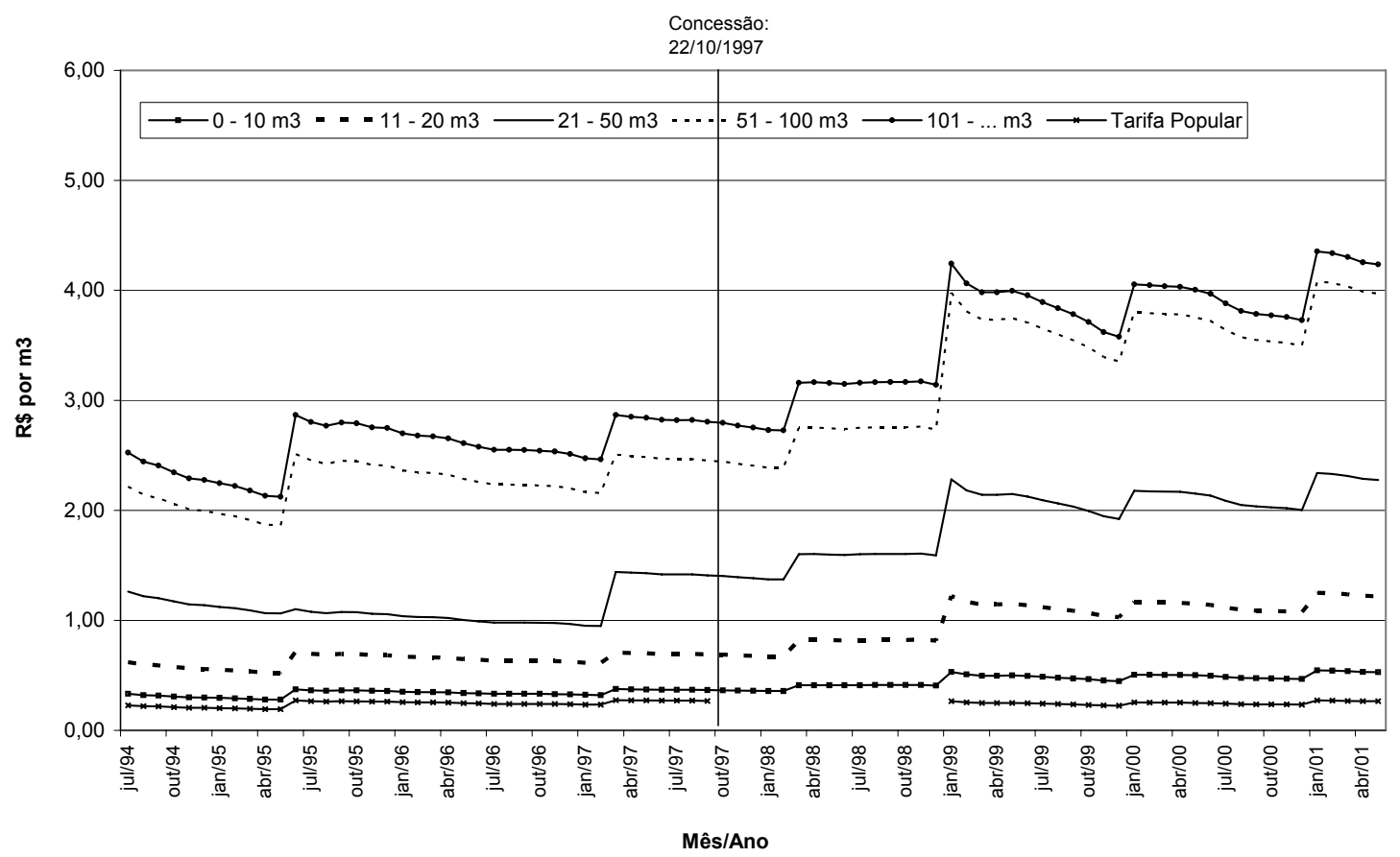

Tabela II - Tarifa de água micromedida conforme o contrato de concessão

\begin{tabular}{|c|c|c|}
\hline \multicolumn{2}{|c|}{ Residencial } & $\mathrm{R} \$$ por $\mathrm{m}^{3}$ \\
\hline 0 & 10 & 0,30 \\
\hline 11 & 20 & 0,60 \\
\hline 21 & 50 & 1,17 \\
\hline 51 & 100 & 2,01 \\
\hline 101 & $\ldots$ & 2,31 \\
\hline \multicolumn{2}{|c|}{ Industrial } & $\mathrm{R} \$$ por $\mathrm{m}^{3}$ \\
\hline 0 & 10 & 1,50 \\
\hline 11 & 20 & 1,80 \\
\hline 21 & 50 & 2,10 \\
\hline 51 & 100 & 2,40 \\
\hline 101 & $\ldots$ & 2,70 \\
\hline
\end{tabular}

\begin{tabular}{|c|c|c|}
\hline \multicolumn{2}{|c|}{ Comercial } & \multirow{2}{*}{$\begin{array}{c}\mathrm{R} \$ \text { por } \mathrm{m}^{3} \\
1,20\end{array}$} \\
\hline 0 & 10 & \\
\hline 11 & 20 & 1,50 \\
\hline 21 & 50 & 1,80 \\
\hline 51 & 100 & 2,10 \\
\hline 101 & $\ldots$ & 2,40 \\
\hline \multicolumn{2}{|c|}{ Pública } & $\mathrm{R} \$$ por $\mathrm{m}^{3}$ \\
\hline 0 & 10 & 0,45 \\
\hline 11 & 20 & 0,60 \\
\hline 21 & 50 & 0,75 \\
\hline 51 & 100 & 0,90 \\
\hline 101 & $\ldots$ & 1,05 \\
\hline
\end{tabular}


A tabela tarifária definida para a concessionária de Petrópolis no contrato vigorou pela primeira vez em março de 1998. Em janeiro de 1999 foi feita uma grande revisão de preços e passou a vigorar uma nova TRA de $\mathrm{R} \$$ 0,3944, com um aumento de 31,46\% em relação à tabela original. Esse aumento superou muito a inflação do período, o que significa que houve uma revisão, e não um mero reajuste de preços, apenas cerca de um ano depois de iniciada a concessão.

Esta revisão introduziu outras modificações: a tarifa de esgoto passou a ser 93,8\% da TRA e não $80 \%$ como previsto no contrato original; criou-se uma nova tarifa para quem tinha coleta e não tinha tratamento de esgoto de $56,2 \%$ da TRA; restabeleceu-se a tarifa popular com um valor de $50 \%$ da conta mínima residencial que havia sido eliminada na privatização; e alteraram-se os coeficientes da política tarifária predefinida, o que implicou aumentos adicionais de $10 \%$ a $15 \%$ para as faixas intermediárias de consumo residencial. Como resultado dessas modificações, pode-se observar uma tendência ao aumento real de preços.

\section{III.3 Águas do Juturnaíba}

A política tarifária implementada pela Águas do Juturnaíba significou uma grande mudança em relação à política da CEDAE. A cobrança passou a ser direta, e não mais escalonada em blocos, e foram introduzidas muitas faixas novas para o consumo residencial. A eliminação da cobrança em cascata aumentou o valor das contas para todas as faixas de consumo acima da mínima porque acabou com o desconto para as primeiras unidades consumidas. A divisão das faixas antigas em blocos menores também aumentou o valor das contas porque passou a cobrar preços diferenciados (crescentes) para uma faixa que tinha o mesmo preço em toda sua amplitude.

A política de tarifas mínimas também foi alterada com a privatização. Passou-se a levar em consideração na formação dos preços o diferencial de renda entre a população residente e a flutuante (turistas). Assim, a tarifa mínima adotada para a classe de consumo residencial foi estabelecida como sendo o maior dos dois valores a seguir definidos: $10 \mathrm{~m}^{3}$ por mês ou $65 \%$ do maior consumo mensal verificado nos últimos 12 meses. Essa regra de discriminação de preços baseou-se no fato de que o consumo estimado da população de maior renda (turistas) era muito alto na temporada e muito baixo em outros períodos. Já os residentes tinham um consumo muito mais equilibrado ao longo do ano. Portanto, os de maior renda seriam obrigados a pagar $65 \%$ do consumo da temporada mesmo em outros períodos, contribuindo, assim, para o financiamento da instalação da capacidade excedente. Para os imóveis residenciais não-hidrometrados, situados nas áreas de baixa renda, o consumo mínimo foi fixado em $15 \mathrm{~m}^{3}$ por mês.

Tais modificações foram feitas com o objetivo de aumentar a receita do monopólio mediante a discriminação de preços (entre residentes e veranistas) e a possibilidade de cobrança de contas de valor muito mais elevado para as classes de consumo mais altas. As tarifas de esgoto foram fixadas no mesmo valor das tarifas de água, e o consumidor com abastecimento próprio de água teve que pagar à concessionária pela coleta e tratamento do esgoto.

A estrutura tarifária da empresa para o consumo micromedido de água, tal como aparece no contrato de concessão, é exibida no Gráfico III. O contrato de concessão publica ainda uma tabela para cobrança das ligações não-hidrometradas com preços inferiores para o consumo estimado. Esta medida traz um incentivo à hidrometração, na medida em que, nesse caso, a empresa pode cobrar preços mais altos. Este incentivo é menor do que no caso de Limeira e Águas do Imperador, quando, após um determinado prazo, todas as ligações de consumo estimado pagariam a conta mínima. 
Gráfico III - Águas de Juturnaíba - Tarifa residencial de água para os consumos abaixo especificados (valores em $\mathbf{R} \$$ de junho de 2001 corrigidos pelo IGP-DI)

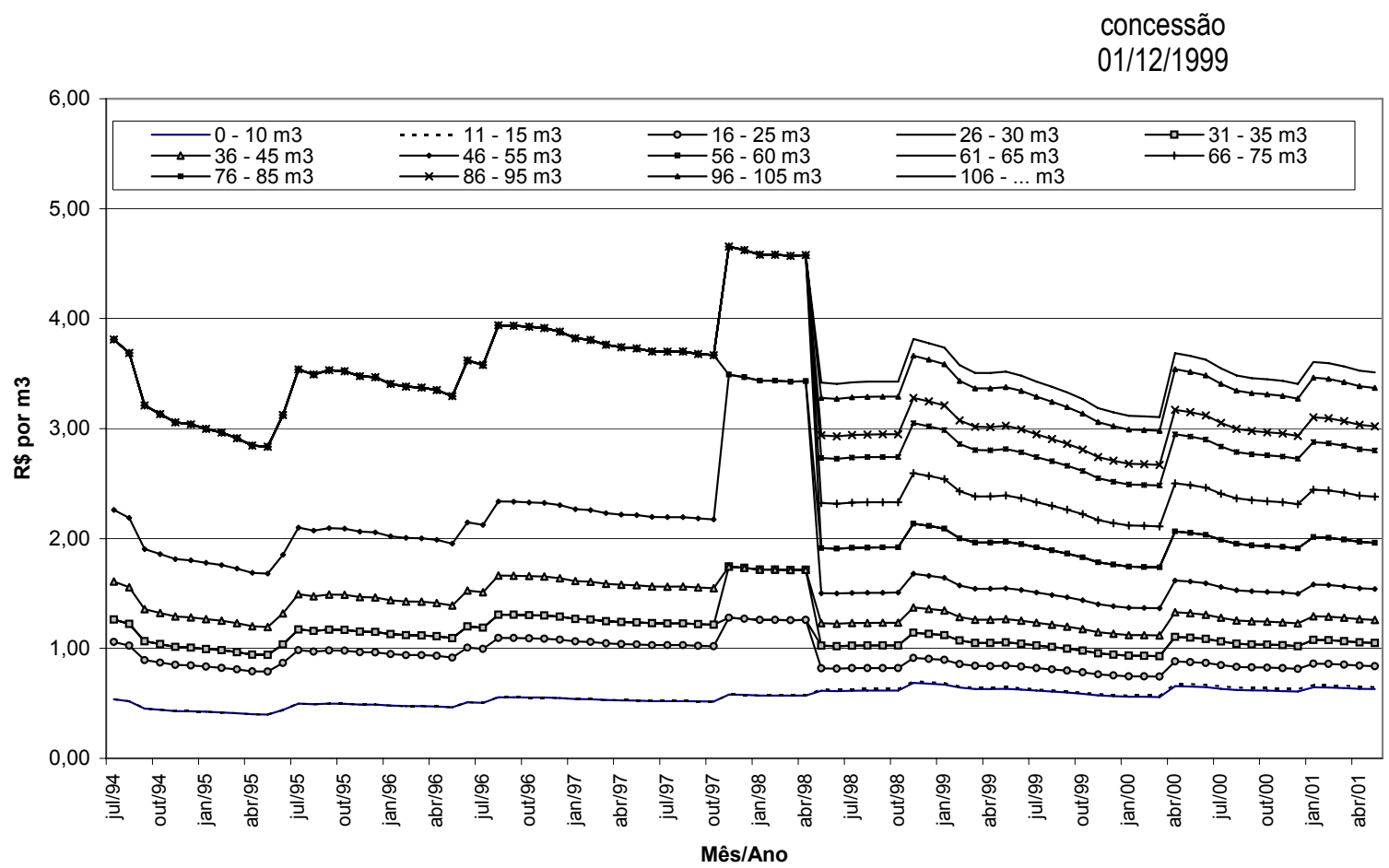

Tabela III - Tarifa de água micromedida conforme o contrato de concessão

\begin{tabular}{ccc}
\hline \multicolumn{2}{c}{ Residencial } & $\mathrm{R} \$$ por $\mathrm{m}^{3}$ \\
\hline 0 & 10 & 0,45 \\
11 & 15 & 0,46 \\
16 & 25 & 0,60 \\
26 & 35 & 0,75 \\
36 & 45 & 0,90 \\
46 & 55 & 1,10 \\
56 & 65 & 1,40 \\
66 & 75 & 1,70 \\
76 & 85 & 2,00 \\
86 & 95 & 2,15 \\
96 & 105 & 2,40 \\
106 & $\ldots$ & 2,50 \\
- & - & - \\
\hline
\end{tabular}

\begin{tabular}{|c|c|c|}
\hline \multicolumn{2}{|c|}{ Comercial } & \multirow{2}{*}{$\begin{array}{l}\mathrm{R} \$ \text { por } \mathrm{m}^{3} \\
1,33\end{array}$} \\
\hline 0 & 20 & \\
\hline 21 & 30 & 1,90 \\
\hline 30 & $\ldots$ & 2,90 \\
\hline \multicolumn{2}{|c|}{ Industrial } & $\mathrm{R} \$$ por $\mathrm{m}^{3}$ \\
\hline 0 & 20 & 2,15 \\
\hline 21 & 30 & 2,40 \\
\hline 30 & ... & 2,90 \\
\hline \multicolumn{2}{|c|}{ Pública } & $\mathrm{R} \$$ por $\mathrm{m}^{3}$ \\
\hline 0 & 20 & 0,60 \\
\hline 21 & 30 & 0,80 \\
\hline 30 & $\ldots$ & 1,20 \\
\hline
\end{tabular}


O Gráfico III mostra a evolução das tarifas cobradas pela Águas do Juturnaíba desde o Plano Real até abril de 2001. A nova estrutura tarifária começou a vigorar em maio de 1998. Em novembro de 1998, em abril de 2000 e em janeiro de 2001 as tarifas cobradas foram aumentadas por autorização da ASEP - Agência Reguladora dos Serviços Públicos Concedidos do Estado do Rio de Janeiro, respectivamente 11\%, 18,7\% e 6,2\%. Embora o gráfico mostre que não houve um aumento substancial de preços após a privatização, a introdução de novas faixas de consumo e a eliminação da cobrança em blocos aumentaram muito a receita da concessão porque elevaram o valor médio das contas.

\section{III.4 Prolagos}

A privatização da Prolagos foi feita no mesmo modelo de Juturnaíba. O Gráfico IV mostra a política tarifária para o consumo hidrometrado de água, de acordo com o contrato de concessão. A nova estrutura tarifária só foi implementada em março de 1999, já incluído um reajuste de 9,75\%. Os novos preços não foram implementados anteriormente porque algumas exigências do cronograma de obras não haviam sido atendidas pela concessionária. De março de 1999 a janeiro de 2001, os aumentos autorizados pela ASEP foram: 18,7\% em abril de 2000 e 6,8\% em janeiro de 2001.

Gráfico IV - ProLagos - Tarifa residencial de água para os consumos abaixo especificados (valores em $R \$$ de junho de 2001 corrigidos pelo IGP-DI)

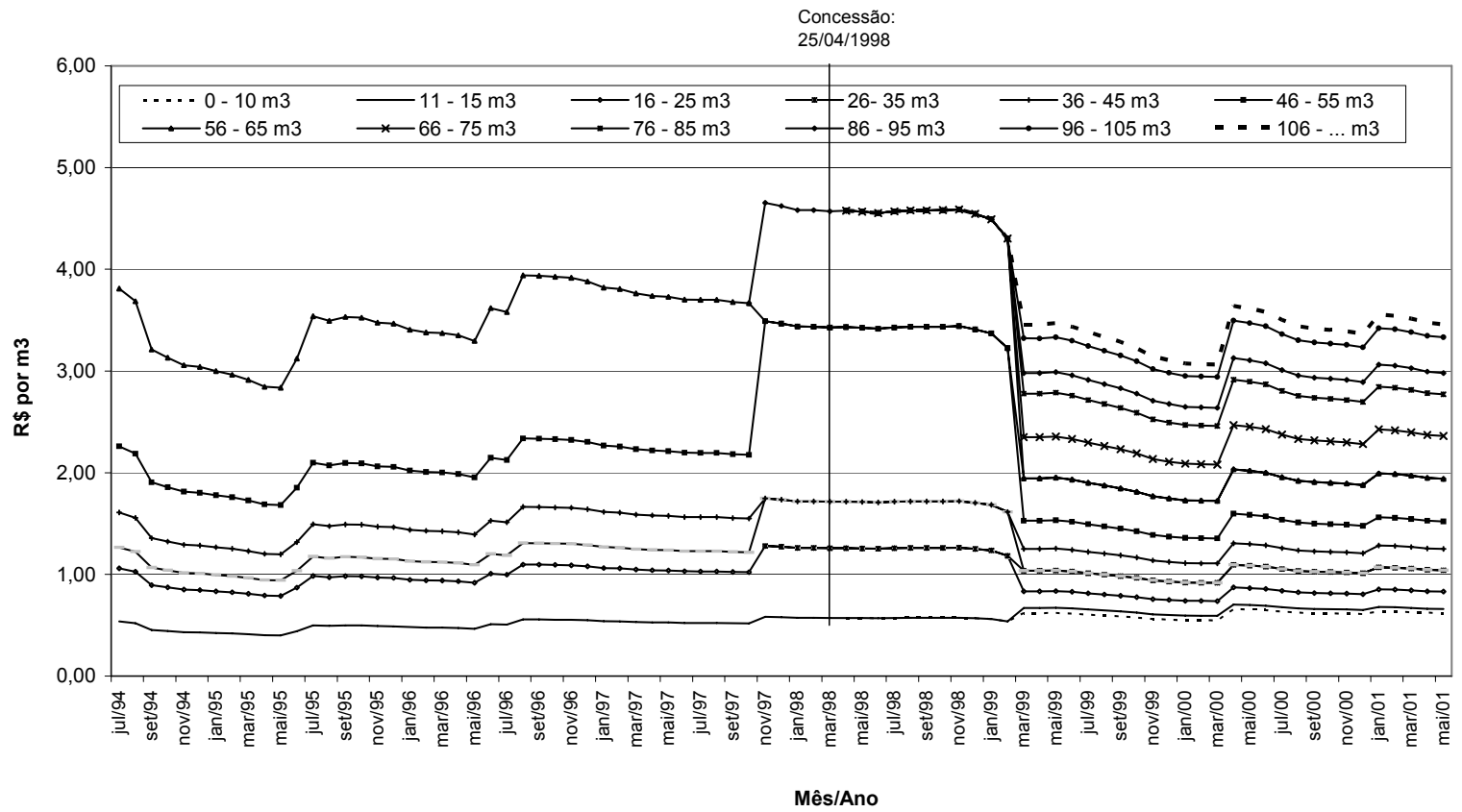


Tabela IV - Tarifa de água micromedida conforme o contrato de concessão

\begin{tabular}{ccc}
\hline Residencial & & $\mathrm{R} \$$ por $\mathrm{m}^{3}$ \\
\hline 0 & 10 & 0,45 \\
11 & 15 & 0,48 \\
16 & 25 & 0,60 \\
26 & 35 & 0,75 \\
36 & 45 & 0,90 \\
46 & 55 & 1,10 \\
56 & 65 & 1,40 \\
66 & 75 & 1,70 \\
76 & 85 & 2,00 \\
86 & 95 & 2,15 \\
96 & 105 & 2,40 \\
106 & $\ldots$ & 2,50 \\
- & - & - \\
\hline
\end{tabular}

\begin{tabular}{|c|c|c|}
\hline \multicolumn{2}{|c|}{ Comercial } & $\mathrm{R} \$$ por $\mathrm{m}^{3}$ \\
\hline 0 & 20 & 1,40 \\
\hline 21 & 30 & 1,90 \\
\hline 30 & $\ldots$ & 2,90 \\
\hline \multicolumn{2}{|c|}{ Industrial } & $\mathrm{R} \$$ por $\mathrm{m}^{3}$ \\
\hline 0 & 20 & 2,15 \\
\hline 21 & 30 & 2,40 \\
\hline 30 & $\ldots$ & 2,90 \\
\hline \multicolumn{2}{|c|}{ Pública } & $\mathrm{R} \$$ por $\mathrm{m}^{3}$ \\
\hline 0 & 20 & 0,60 \\
\hline 21 & 30 & 0,80 \\
\hline 30 & $\ldots$ & 1,20 \\
\hline
\end{tabular}

\section{III.5 Comparação do valor das contas}

O Gráfico V, construído com as tarifas em vigor em junho de 2001, permite comparar o valor total das contas que seriam cobradas aos consumidores pelas quatro empresas analisadas para o consumo residencial de cada $\mathrm{m} 3$ de água até $140 \mathrm{~m} 3$ por mês. Observa-se que o valor das contas cobradas pelas concessionárias da região dos Lagos é mais elevado do que as contas de Limeira ou de Petrópolis para quase todos os níveis de consumo. Esta diferença é tanto maior quanto maior o volume de água consumido em conseqüência da eliminação da tarifação em bloco feita por estas empresas. ${ }^{12} \mathrm{O}$ valor da conta de Limeira é sempre o menor.

\section{Gráfico V - Valor da conta de água por empresa - junho de 2001 (inclusive taxas e ICMS)}

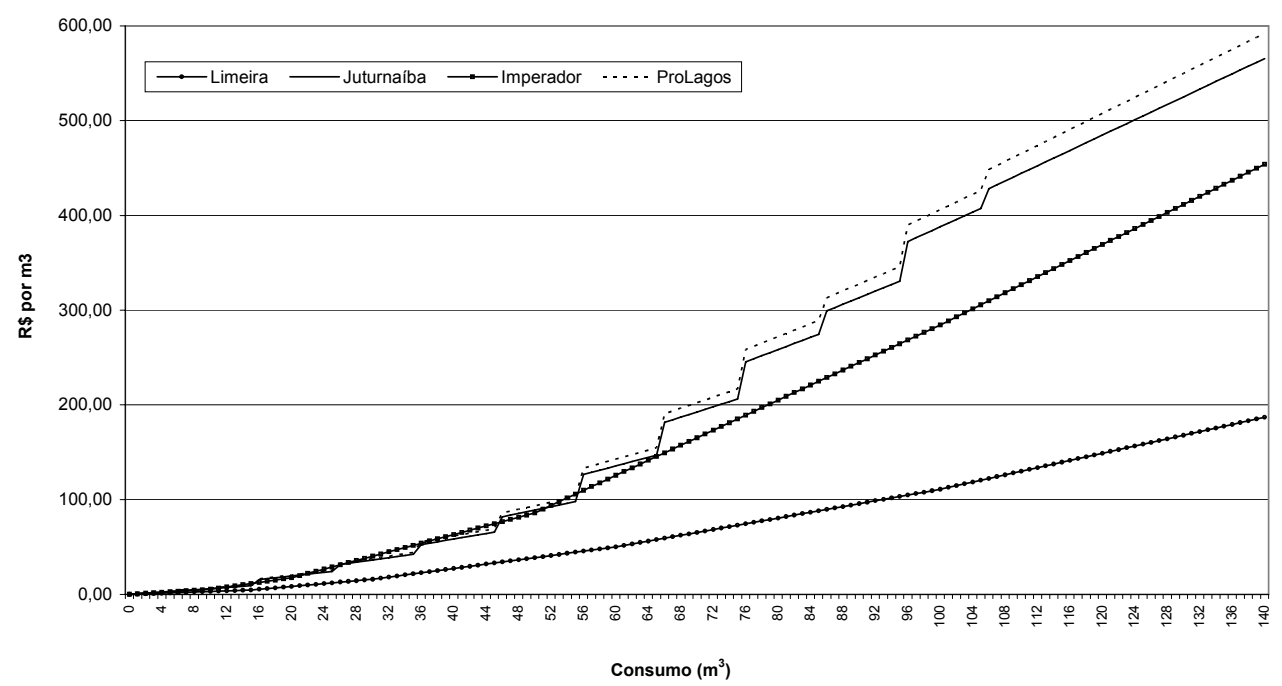

12 A eliminação da tarifação em bloco e sua substituição por uma tarifa direta têm o mesmo efeito de passar-se a cobrar o imposto de renda utilizando apenas a alíquota marginal de cada contribuinte. 


\section{REgulaÇão}

\section{IV.1 Agências reguladoras}

A atividade de regulação é exercida de modo diferente para cada uma das concessões. No caso das concessões de Limeira e Petrópolis, a antiga concessionária estatal foi nomeada para fazer o serviço de regulação, inclusive a aprovação de revisões e atualização das tarifas sem nenhuma modificação estrutural significativa, demonstrando a pouca atenção que mereceu a questão até o momento no Brasil. Em Limeira, o regulador é o SAAE - Serviço Autônomo de Água e Esgoto e, em Petrópolis, a CAEMPE - Companhia de Água e Esgoto do Município de Petrópolis. No caso dos balneários fluminenses, o governo estadual criou uma agência reguladora que não é especializada em água, como seria desejável, ASEP-RJ - Agência Reguladora de Serviços Públicos Concedidos do Estado do Rio de Janeiro.

O padrão de qualidade dos serviços é determinado também de forma diferente em cada uma das concessões. Em Limeira, serão respeitados os padrões de qualidade definidos pelo Ministério da Saúde para a água e as leis estaduais para avaliação de esgotos sanitários, além de Normas da ABNT referentes a estudos e projetos de saneamento.

$\mathrm{Na}$ área de Petrópolis o padrão para a água é o definido pelo Ministério da Saúde (como em Limeira). Mas o contrato de concessão estabeleceu um prazo de 4 anos para a concessionária eliminar o problema da água turva em razão do mau estado de conservação da rede de distribuição, que é muito antiga. Em Juturnaíba o padrão é definido pelo Regulamento dos Serviços Públicos de Abastecimento de Água e Esgotamento Sanitário do Estado do Rio de Janeiro. No caso da Prolagos menciona-se este regulamento e o Código de Defesa do Consumidor, além de Normas da ABNT.

As multas aplicadas aos concessionários são receita da CAEMPE em Petrópolis e divididas entre os poderes concedentes na mesma proporção do valor da outorga no caso da Prolagos e Águas do Juturnaíba. Esta situação é indesejável, pois embute um incentivo ao regulador para a imposição de multas.

\section{2 Revisões e reajustes de preços}

A leitura dos contratos de concessão permite concluir que não há clareza quanto à política de regulação que os novos reguladores pretendem seguir. Apesar dos leilões envolverem a fixação de preços, a questão dos reajustes e revisões ${ }^{13}$ parece voltada para a regulação pela taxa de retorno. Em primeiro lugar, a regra de reajuste de preços nem sempre é clara. A transcrição da cláusula referente a reajustes de Limeira exemplifica a questão. "As tarifas serão reajustadas com base na variação do indice da mão-de-obra da construção civil, tarifa de energia elétrica, índice da indústria de transformação química, índice nacional da construção civil, índice de máquinas, veículos e equipamentos, índice de variação cambial e índice de juros aplicáveis ao financiamento nacional e internacional. As partes deverão apurar o impacto na TRA de cada um dos índices citados, para estabelecerem de comum acordo uma ponderação dos mesmos para servir de base ao reajuste."

Esta cláusula totalmente indefinida permitiu que a concessionária ficasse sem qualquer reajuste de preços por quase seis anos. Ao cabo deste período, foi autorizado um reajuste de 63,4\%.

13 Nos contratos de concessão as expressões "Atualização" ou "Reajuste” têm significado diferente de "Revisão". As duas primeiras expressões fazem referência à indexação. "Atualização" diz respeito a índices gerais de preços enquanto o "Reajuste" refere-se a índices setoriais. Por outro lado, as "Revisões" dizem respeito à adaptação a fatos novos, imprevistos ou inevitáveis. 
Em contrapartida, a empresa assumiu dívidas de $\mathrm{R} \$ 24,5$ milhões da antiga concessionária municipal. Apesar de vaga, a cláusula pretendia conter uma proteção contra a variação cambial.

No que diz respeito à revisão das tarifas, os contratos analisados são muito vagos e praticamente garantem taxas mínimas de retorno dentro do conceito de equilíbrio econômico-financeiro. As cláusulas referentes à revisão do contrato de Águas do Imperador não só deixam a questão em aberto como estabelecem penalidades para o regulador: "Não há periodicidade fixa. As revisões vão ocorrer sempre que ocorrerem motivos técnicos, econômicos, financeiros, tributários ou conjunturais que possam comprometer a cobertura dos custos dos investimentos, dos custos operacionais e de manutenção, afetando o equilíbrio econômico-financeiro do contrato." E mais adiante "Caso a Concedente, por razões de interesse público devidamente fundamentadas, decida não autorizar o reajuste e/ou revisão das tarifas e a tabela de prestação de serviços, quando estes se fizerem necessários, em decorrência de quaisquer motivos causadores do desequilíbrio econômico-financeiro do contrato, a própria concedente será responsável pelo reembolso mensal à subconcessionária dos valores necessários à retomada do referido equilíbrio do contrato, devendo em tais casos oferecer garantias reais prévias à subconcessionária quanto à disponibilidade própria de tais recursos." Também o contrato de Limeira reza que revisões podem ser feitas a qualquer momento para manter o equilíbrio econômico-financeiro do contrato.

Já o contrato da Águas do Juturnaíba dispõe que a concessionária terá direito a revisão do valor da tarifa básica como contrapartida dos riscos assumidos, ou seja, como uma forma de neutralizar os riscos para o novo concessionário. O Contrato registra ainda o seguinte: "Não há periodicidade fixa. A revisão é feita sempre que forem constatadas modificações estruturais nos preços relativos dos fatores de produção ou modificações substanciais nos preços dos insumos relativos aos principais componentes de custos considerados na formação do Valor da Outorga da Concessão, não atendidas ou cobertas pelos reajustes tarifários previstos no contrato." E determina uma grande flexibilidade no critério revisional: "Sempre que haja lugar para a revisão da tarifa básica da concessão, o poder concedente e a concessionária poderão acordar complementar ou alternativamente ao aumento do valor da tarifa, pela antecipação ou prorrogação do prazo da concessão, pela atribuição de compensação direta à concessionária e qualquer alternativa que venha a ser acordada entre as partes."

O contrato da Prolagos, por sua vez, é muito semelhante ao de Juturnaíba no que diz respeito à revisão de tarifas e toma a iniciativa de proteger as empreiteiras do risco de construção, o que não seria necessário, ao determinar em referência à construção da barragem do rio Juturnaíba que: "Caso os custos efetivamente apurados para a manutenção corretiva da barragem do Rio Juturnaíba, ao longo do período de concessão, ficarem abaixo ou excederem os valores atribuídos no quadro 6 do Anexo II, estes valores para mais e para menos, farão parte do processo de revisão de tarifa."

A análise das cláusulas de revisão mostra que não há critérios definidos para a alocação dos riscos e aparentemente todos devem ser cobertos pelos consumidores mediante "revisões da política tarifária”. Este sistema não contém os incentivos adequados à redução de custos. Na prática isto significa que sempre que a taxa de retorno cair, o concessionário pode pedir que seu valor seja revisto, mas o contrato não dá garantias de que isto será feito, abrindo amplo espaço para captura da agência reguladora e manipulação política em geral.

No passado recente, alguns grandes consumidores industriais de água recusaram-se a pagar a conta de esgotamento com base no seu consumo de água alegando que a água é para eles matériaprima e, conseqüentemente, não gera o mesmo volume de esgoto. ${ }^{14}$ Tal alegação chama a atenção para a artificialidade do expediente de cobrar o esgoto pelo fornecimento de água. $\mathrm{O}$ contrato de concessão de Petrópolis antecipa-se a este problema ao determinar que "Para as ligações às redes coletoras de efluentes industriais o valor da conta mensal será obtido com base no volume de água forneci-

$14 J B$ de 19/09/99. 
do pela subconcessionária ou no volume total de efluentes lançados à rede tratados ou não, tomando-se o maior deles... ."

Também tem sido contestada a prática de cobrar pelo serviço de esgotamento ainda que ele não tenha sido prestado. Na maioria das localidades brasileiras é exatamente isto que acontece. Em 1999, a Câmara de Vereadores de São Pedro da Aldeia, município da área de concessão da Prolagos, aprovou uma lei, que foi sancionada pelo prefeito, que criou uma nova regra para a cobrança dos serviços de esgoto da cidade. Esta nova lei n⿳ํํ 1318 diz que a Prolagos só pode cobrar pelo esgotamento onde houver efetivamente rede de esgotos sanitários com tratamento adequado na sua totalidade.

Esta decisão da Câmara de Vereadores está em franco desacordo com as regras sob as quais a Prolagos participou da licitação da concessão. O edital da privatização estabelecia a cobrança do esgotamento e, portanto, esta lei rompe o equilíbrio econômico-financeiro do contrato da Prolagos e exemplifica o risco regulatório destes concessionários pioneiros. O Contrato de Concessão de Petrópolis, antecipando este tipo de problema, estabelece que o esgoto só será cobrado do usuário que tenha o serviço de coleta à sua disposição. Numa revisão de sua política tarifária feita já no decurso da concessão, a Águas do Imperador estabeleceu duas tarifas para o serviço de esgotamento, diferenciando preços para coleta e tratamento dos preços para a simples coleta.

O desconforto em relação à tarifação do esgoto pode ser ilustrado ainda com o fato de que, em Limeira, num documento em separado chamado Regulamento da Comercialização é feito um esforço de aproximar a tarifa de esgoto ao custo de atendimento. É dito que "A tarifa de esgoto será fixada com base na tarifa de água e, em determinados casos, acrescida de uma parcela relativa ao grau poluente do efluente, de conformidade com as normas do concessionário." Dentro desta mesma linha de raciocínio, o Contrato de Concessão do município de Petrópolis estabelece que a tarifa de esgoto pode ser modificada no caso dos efluentes industriais de acordo com sua DBO (Demanda Bioquímica de Oxigênio) ou DQO (Demanda Química de Oxigênio), e do teor de sólidos em suspensão expressos em kg por mês.

Os Contratos de Concessão de Águas do Juturnaíba e da Prolagos estabelecem que a concessionária terá a responsabilidade de somente coletar e tratar esgotos de origem doméstica. As empresas, indústrias e outras instituições que têm seus efluentes com outras características que não as domésticas serão obrigadas a tratá-las previamente, de forma a só lançar nas redes coletoras esgotos dentro dos parâmetros domésticos.

\section{IV.3 Inadimplência}

Em todas as concessões analisadas há incentivos à instalação de hidrômetros e os contratos determinam que a concessionária tem obrigação de interromper o fornecimento em caso de inadimplência. Ainda vai levar um tempo até que esta ameaça seja efetiva. Em todas as concessões analisadas os consumidores que têm fonte de água própria devem instalar um hidrômetro e pagar a concessionária pelo serviço de coleta e tratamento de esgoto (Limeira e Petrópolis), ou pagar por estes serviços por estimação (Juturnaíba e Prolagos). ${ }^{15}$ Os roubos de água (gatos) são feitos com muita facilidade, e é comum que os consumidores cujo fornecimento seja cortado por falta de pagamento jamais apareçam para reclamar ou solicitar a religação. A inadimplência e as perdas, comerciais e técnicas, são talvez os principais problemas a serem enfrentados pelos novos concessionários.

15 Este nem sempre é o arranjo. Por exemplo, em Buenos Aires a concessionária tem o direito de lacrar e impedir a utilização de fontes alternativas de água. Todos os consumidores devem ligar-se obrigatoriamente à rede. 
Tanto no caso da Prolagos como em Juturnaíba, os hidrômetros das novas ligações devem ser pagos pelo consumidor, comprometendo-se a nova concessionária a fornecer, reparar e instalar hidrômetros, a sua expensas, para os usuários já cadastrados na CEDAE até o mês anterior ao da entrega das propostas.

\section{IV.4 Arbitragem}

Antecipando-se às dificuldades de recorrer à justiça para a solução de cada um dos conflitos de interesse entre os reguladores e as empresas reguladas, alguns contratos estabelecem instâncias intermediárias para a solução de conflitos. Em Limeira esta providência não foi tomada.

Para a área de Petrópolis, o contrato de concessão estabelece dois conselhos previamente organizados para resolver as desavenças entre o poder concedente e o subconcessionário. $\mathrm{O}$ primeiro deles é uma Comissão de Peritos com 3 membros nomeados de comum acordo. O segundo é um Tribunal Arbitral também com 3 membros sendo um nomeado pelo poder concedente, um pelo subconcessionário e um terceiro um advogado de grande renome na área de concessões nomeado de comum acordo. Se o parecer da Comissão de Peritos não produzir um consenso, a questão é submetida ao Tribunal Arbitral. O Tribunal Arbitral julgará segundo o direito constituído e suas decisões terão força normativa, independentemente de homologação judicial, prevalecendo sempre o princípio da legalidade e/ou da principal indisponibilidade do interesse público.

Em Araruama também estava previsto um "Processo de Solução de Divergências". Seriam constituídas duas Comissões de Peritos: uma para questões de natureza técnica (Comissão Técnica) e outra para questões financeiras (Comissão Econômica e Financeira). Caso a solução dos peritos não fosse aceita, a questão deveria ser submetida a um Tribunal Arbitral. A designação dos membros das comissões técnica e econômica seria feita de comum acordo entre o regulador e a concessionária, devendo duas vagas em cada Comissão serem preenchidas por um engenheiro e um advogado com experiência na área. No Tribunal Arbitral, cada parte indicaria um membro e a escolha do terceiro seria feita de comum acordo, devendo recair num advogado com experiência comprovada.

Entretanto, o contrato de concessão estipulou que quando o Ente Regulador fosse criado, o Tribunal Arbitral seria extinto e o processo de solução de divergências seria mediado pelo novo Ente Regulador. Tal providência é descabida, já que estes conselhos consultivos não substituem o regulador, mas servem para auxiliar na arbitragem de divergências entre ele e a concessionária.

\section{IV.5 Externalidades}

Estudos da OMS - Organização Mundial de Saúde mostram que R\$ 1 aplicado em Saneamento gera $R \$ 2,50$ de economia em saúde. As externalidades são também muito grandes na área ambiental. Entretanto, o Brasil está apenas começando o controle destas questões.

O contrato de concessão da Águas do Juturnaíba estabelece que a concessionária enviará à fiscalização trimestralmente um relatório sobre: eventuais impactos ambientais provocados pela conservação e exploração dos sistemas; as ações adotadas para mitigar ou compensar os efeitos dos impactos ambientais provocados; os impactos ambientais previstos e as subseqüentes medidas de mitigação e compensação. O edital estabelece ainda que a eficácia do sistema de tratamento de esgotos será verificada e avaliada em caráter permanente no que diz respeito à qualidade dos efluentes finais das estações. Também a Prolagos deve enviar trimestralmente à agência reguladora um 
relatório sobre os eventuais impactos ambientais provocados pela conservação e exploração dos sistemas.

\section{IV.6 Relatórios de acompanhamento}

Todos os contratos analisados têm metas físicas quantitativas. O acompanhamento do desempenho dos novos concessionários será feito de forma distinta por cada regulador. O Contrato de Concessão de Limeira estabelece que o acompanhamento das metas será feito por meio de relatórios técnicos, com periodicidade variando de trimestral a anual, relatando o desenvolvimento do Plano Especial de Obras aprovado por ocasião da licitação. Não estão definidos mais detalhes a este respeito.

O contrato da Águas do Imperador exige a apresentação de relatórios semestrais dos serviços prestados e dos investimentos feitos e estabelece metas escalonadas no tempo no que se refere ao atendimento e nível de perdas. Ao fim de oito anos, $90 \%$ da população urbana estará recebendo água tratada e o tratamento de esgoto deverá ter atingido $65 \%$ da população urbana. O índice de perdas de água do sistema de distribuição deverá ser reduzido a $25 \%$ até o final da concessão. A modéstia dessas metas chama a atenção para a precariedade do estado da rede por ocasião da concessão e este panorama é o mais comum no Brasil.

A situação se repete no contrato da Águas de Juturnaíba: ao final de seis meses, deverá haver 3000 hidrômetros instalados; ao final do quarto ano, as perdas devem ficar em torno de 30\%; ao fim do terceiro ano, $80 \%$ da população deverá estar recebendo água tratada; ao fim de oito anos, $85 \%$ da população deverá estar recebendo água tratada e $25 \%$ do esgoto estará sendo tratado; ao fim de 13 anos, $90 \%$ para água e $50 \%$ para esgoto; ao fim de 20 anos, $95 \%$ para água e $65 \%$ para esgoto; e finalmente ao cabo de 25 anos, $100 \%$ para água e $70 \%$ para esgoto.

As metas a serem atingidas pela Prolagos são muito semelhantes às da Águas do Juturnaíba, com a diferença que as metas da Prolagos estão referidas aos períodos de pico de demanda, já que a variação de demanda sazonal é muito grande: ao final do terceiro ano da concessão, as metas são $80 \%$ para água e $30 \%$ para esgoto; ao final do oitavo ano, $83 \%$ para água e $40 \%$ para esgoto; ao final do décimo ano $85 \%$ para água e $50 \%$ para esgoto; ao final do décimo-terceiro ano $85 \%$ para água e $65 \%$ para esgoto; e ao final do décimo-quinto ano $90 \%$ para água e $70 \%$ para esgoto.

Tanto no caso da Prolagos, como no caso de Águas do Juturnaíba, a concessionária deverá preparar e apresentar à ASEP-RJ, trimestralmente, um relatório sobre os serviços concedidos, bem como dos investimentos realizados, devendo constar do aludido relatório as atividades ocorridas no trimestre anterior, inclusive faturamento, solicitações de inscrição de novos usuários, e metas da concessão. Por ocasião da assinatura dos contratos, o conteúdo dos relatórios não estava definido. Conforme reza o contrato de concessão "O conteúdo dos relatórios, sua periodicidade e forma de apresentação serão estabelecidos de comum acordo entre o regulador e a concessionária."

\section{CONCLUSÕES}

Neste trabalho analisamos diversos aspectos de quatro concessões ao setor privado da área de saneamento. $\mathrm{Na}$ ausência de regras, as primeiras concessões feitas são verdadeiras aventuras, nas quais os concessionários correm elevados riscos e procuram cobrar por isso. A definição do marco regulatório, que deverá ser feita no futuro próximo, certamente reduzirá o custo dos serviços para o público e aumentará o nível de concorrência pelas concessões ou parcerias. 
Entre os aspectos positivos das experiências analisadas podemos destacar a privatização por municípios que, além de se adequar melhor aos problemas locais, amplia a competição e facilita a participação de empresários de menor porte. A privatização de estados inteiros não é compatível com a autonomia municipal nem com a administração dos recursos hídricos por bacias hidrográficas.

Também argumentou-se que a ênfase na menor tarifa como critério de seleção de propostas tem todas as potencialidades para produzir muito melhores resultados do que os leilões pelo maior valor de outorga e estrutura tarifária definida. A cobrança da outorga onera o concessionário privado e, conseqüentemente, o consumidor, dificultando a transferência dos ganhos da privatização à população mediante a cobrança de tarifas mais baixas. Ainda que se possa concordar com a cobrança, a definição do nível desta tributação deve fazer parte de uma política global e não ser variável de um leilão.

A posição relativamente privilegiada do Brasil no que diz respeito a recursos hídricos abriu espaço para a manutenção da produção para autoconsumo nos novos contratos de concessão. $\mathrm{O}$ fato de que os produtores de água para autoconsumo devem pagar pelo esgotamento também é plenamente justificado pelas externalidades envolvidas nos sistemas inadequados de esgotamento. A implementação da arbitragem também é especialmente adequada para a situação brasileira porque, sabidamente, nossa justiça é muito morosa e despreparada na área de regulação. Iniciativas desse tipo vêm sendo implementadas com sucesso em grandes empresas do setor privado.

Talvez a principal desvantagem das concessões feitas até agora seja o descuido com relação ao sistema de preços. O setor de saneamento precisa de uma reforma total do seu sistema de preços, de forma a aproximá-lo de critérios de eficiência e eqüidade. A fuga desta questão, para não chamar a atenção da discussão política para o programa de privatização, perpetua esta situação ruim.

As metas físicas dos contratos são relativamente modestas. Não prevêem a cobertura total dos serviços, ainda que se espere todo o longo período da concessão, principalmente para a coleta e o tratamento do esgoto. Isto acontece principalmente porque a situação do saneamento no Brasil é realmente muito precária. Por outro lado, as metas físicas em porcentagem não definem quem deve ser atendido prioritariamente, deixando a certeza de que ficarão sem atendimento justamente os mais carentes, menos capazes de pagar pelo serviço.

No caso dos balneários fluminenses, a privatização trouxe modificações para a estrutura tarifária justamente no sentido oposto do que seria desejável. O cálculo das contas passou da forma escalonada para a forma direta, aumentando-se a receita. A criação de muitas faixas novas para o consumo residencial também teve o aumento de receita como único objetivo. Esta política tarifária maximizadora dos ganhos de monopólio não tem naturalmente qualquer relação com um modelo eficiente de tarifação.

A introdução do mecanismo discriminador de preços nas contas mínimas da Região dos Lagos, sim, significou um passo correto no sentido de mais eficiência, procurando cobrar os custos de implementação de um sistema com capacidade muito maior do que o necessário para atender à população residente, daqueles em benefício de quem a expansão seria feita, os turistas. Significou também um passo no sentido da eqüidade, na medida em que a renda da população flutuante era muito mais elevada que a da população residente. ${ }^{16}$

Houve apenas algumas iniciativas tímidas de adequar preços a custos de atendimento mediante a diferenciação da tarifa de esgoto, principalmente no que diz respeito aos consumidores industriais, de quem freqüentemente ou foi exigido o tratamento prévio do esgoto, ou introduzida uma tarifa mais elevada, como forma de custear os gastos do tratamento. Em todos os outros casos, o esgotamento continuou sendo cobrado com base numa determinada proporção da tarifa de água.

16 Infelizmente, a cobrança da conta equivalente a 65\% do maior consumo foi suprimida em 23/03/2000 por determinação da ASEP. 
A segmentação da indústria poderia ter sido feita, já que não há economias de abrangência na prestação dos serviços de fornecimento de água potável e de esgotamento sanitário. Muito pouco tem sido feito em relação à qualidade dos serviços prestados. Não apenas os padrões estão inadequadamente definidos, como a forma de avaliação do desempenho dos concessionários privados também não está determinada.

Num ambiente ideal, a regulação pelo preço admitiria reajustes por fórmulas paramétricas predefinidas, que ao mesmo tempo que reporiam perdas inflacionárias permitiriam o repasse automático da variação de itens de custos sobre os quais o concessionário não tenha qualquer controle. O que se pode perceber é que revisões e reajustes de preços vêm sendo implementados sem critério. As regras de reajuste de preços nem sempre são claras, e a revisão é prevista em muitas hipóteses diferentes, inclusive protegendo o novo concessionário de riscos que ele poderia perfeitamente suportar. Os consumidores são sistematicamente chamados a fazer a cobertura de riscos que poderiam ser muito melhor atribuídos a outros agentes envolvidos no negócio.

Finalmente, o Brasil optou por um modelo de privatização que não transferiu a propriedade dos ativos aos empresários privados, obrigando sua reversão ao controle do Estado findo o prazo da concessão. Urge, portanto, que se pense em formas de criar incentivos para que os concessionários não se desinteressem completamente por sua manutenção ao se aproximar o final do prazo das concessões.

\section{REFERÊNCIAS BIBLIOGRÁFICAS}

Anderson, T.; Hill, P. Water marketing: the next generation. Londres, Reino Unido: Rowman \& Littlefield Publishers, Inc., 1997.

Andrade, T. A. e outros. Estudo da função demanda por serviços de saneamento e estudo da tarifação do consumo residencial de água. Texto para Discussão 438, IPEA, 1996.

Anjos, A. H. O preço da água: alguns aspectos conceituais. SANARE, v. 8, n. 8, jul./dez. 1997.

Artana, D.; Navajas 7, F.; Urbiztondo, S. Governance and regulation: a tale of two concessions in Argentina. In: Savedoff, W.; Spiller, P., Spilled water. Washington, D. C. EUA: Interamerican Development Bank, 1999.

Azevedo, L. T.; Asad, M. The political process behind the implementation of bulk water pricing in Brazil. In: Dinar, A. (ed.), The political economy of water pricing reforms. Oxford University Press, 2000.

Boland, J.; Wihttington, D. Water tariff design in developing countries. In: Dinar, A. (ed.), The political economy of water pricing reforms. Oxford University Press, 2000.

Engel, E.; Fisher, R.; Galetovic, A. A new mechanism to auction highway franchises. Documentos de Trabajo $\mathrm{n}^{\mathrm{o}}$ 13, Santiago, Chile: Centro de Economia Aplicada, Universidade do Chile, 1996.

Gleick, P. H. Basic water requirements for human activities: meeting human needs. Water International, v. 21, n. 2, 1996.

Haro, A.; Moita, C.; Bitu, R. Tarifação eficiente para o setor de saneamento. Projeto de Modernização do Setor de Saneamento, Custos de Referência, v. 1, Brasília, D.F.: IPEA - Instituto de Pesquisa Econômica Aplicada, 1966.

Hyman and others. The water business: understanding the water supply and wastewater industry. Virginia, E.U.A., 1998.

Idelovitch, E.; Ringskog, K. Private sector participation in water supply and sanitation in Latin America. Washington, D.C. (E.U.A.): The World Bank, 1995. 
Mann, P. C. Assesing the applicability of selected financial incentive regulation methods for water utility regulation. Columbus, Ohio, E.U.A.: The National Regulatory Research Institute, The Ohio State University, 1997.

Ministério do Planejamento e Orçamento. Sistema nacional de informações sobre saneamento. Secretaria de Política Urbana, PMSS - Programa de Modernização do Setor de Saneamento, 1999.

Morandé, F.; Dona, J. E. Governance and regulation in Chile: fragmentation of the public water sector. In: Savedoff, W.; Spiller, P., Spilled water. Washington, D. C. (EUA): Interamerican Development Bank, 1999.

Ozuna, T.; Gomez, I. A. Governance and regulation: decentralization in Mexican water sector. In: Savedoff, W.; Spiller, P., Spilled water. Washington, D. C. (EUA): Interamerican Development Bank, 1999.

Spiller, P. T.; Savedoff, W. Government opportunism and the provision of water. In: Savedoff, W.; Spiller, P., Spilled water. Washington, D. C. (EUA): Interamerican Development Bank, 1999.

Stone \& Webster Consultants. Investigation into evidence for economics of scale in the water and sewerage industry in England and Wales. Final report, Office of Water, January, 2004.

United Nations. Agenda 21: The United Nations programme of action from Rio. Nova Iorque, 1993.

WHO (World Health Organization). Health and environment in sustainable development: five years after the earth summit. Genebra, 1997. 